\title{
New approaches to the diagnosis of psychopathy and personality disorder
}

\author{
Peter Tyrer MD FRCPsych
}

No-one doing research on personality disorder is satisfied with the current diagnostic systems. Like a baker without a rolling pin, the clinician has a rough idea of what personality disorder is and how it should be described, but with the diagnostic implements at his disposal he can only produce a lumpy imitation of what he really wants. The many deficiencies of the current ICD and DSM diagnostic systems seem to derive from the simple error of assuming that personality disorders could be classified in the same way as mental state disorders, by use of well-defined symptoms or characteristics that are (ideally) pathognomonic. Nearly a quarter of a century after the introduction of such operational criteria by the American Psychiatric Association in DSM-III ${ }^{1}$ we realize why the diagnostic experiment for personality disorders has failed.

\section{EXISTING CLASSIFICATION AND REASONS FOR ITS FAILURE}

Before 1980 the classification of personality disorder was almost anarchic. The main influence was that of Schneider, ${ }^{2}$ who had described ten types of personality as part of what he (confusingly in retrospect) termed psychopathy. These were the hyperthymic, depressive, insecure, fanatical, selfseeking, emotionally unstable, explosive, affectless, weakwilled and asthenic personalities. Not many classifications based on a single person's intuition have lasted over threequarters of a century, but in slightly different forms some of Schneider's types survive in the current classificationnamely the insecure (obsessive-compulsive or anankastic), self-seeking (histrionic), emotionally unstable (borderline and impulsive), explosive (antisocial and also impulsive), and affectless (schizoid but also including some now called psychopathic in a different sense) personality disorders. The DSM Task Force that was charged with revising the classification of personality disorder had very little empirical evidence to go on in making their judgments and took as their benchmark early studies that used research diagnostic criteria to define conditions such as depression and

Department of Psychological Medicine, Imperial College, Claybrook Centre, London W8 8RP, UK

E-mail: p.tyrer@imperial.ac.uk schizophrenia. Their use of similar criteria to define personality disorder had calamitous results.

Although the general criteria for diagnosing personality disorder-pervasive pattern of maladaptive traits and behaviours beginning in early adult life and persisting at least to middle age, often improving in old age; conditions leading to significant personal distress and/or social dysfunction and disruption to others - were a reasonable synthesis in the light of knowledge at the time, the description of the individual disorders was awry. It used operational criteria to define ideal or prototypical manifestations that could be regarded as exemplars of each disorder. Two things were wrong with this approach. First, it assumed that personality disorders, conditions assumed to persist over long periods, could be clearly distinguished from normal variation and other mental disorders by this method; and, secondly, it made the mistake of assuming that the Schneiderian personality types were valid. It was an understandable mistake, since we all like to pigeon-hole people into entities that we can identify clearly so as to predict their behaviour. Unfortunately, unlike the characters from Charles Dickens' novels who behave in the same inimitable manner whenever they are encountered, real people are unpredictable and, when disordered, seldom show the 'pure' disturbance specified by the model.

\section{WHAT IS IMPORTANT FOR THE CLINICIAN TO KNOW ABOUT PERSONALITY AND PERSONALITY DISORDER?}

For the practising clinician it is important to derive five implications from a diagnosis - to provide reliable understandable groupings that aid communication and research; to identify separate homogeneous types of disorder (carving nature at its joints); to help the clinician in making decisions about clinical management; to improve prediction and prognosis of each defined condition; and to aid research into the causes and nature of the identified disorders.

\section{Reliable understandable homogeneous groupings}

Since Schneider's time the search for reliable and understandable groupings has continued but the simple categorical types introduced by him have proved illusory. 
Table 1 The cluster system of diagnosis of personality disorder

\begin{tabular}{ll}
\hline Cluster & Personality disorders included in cluster \\
\hline A & ICD-10: schizoid, paranoid \\
& DSM-IV: schizoid, schizotypal, paranoid \\
B & ICD-10: dissocial, emotionally unstable \\
& (borderline and impulsive), histrionic \\
& DSM-IV: antisocial, borderline, histrionic, \\
& narcissistic \\
C & ICD-10: anxious, dependent \\
& DSM-IV: avoidant, dependent \\
D (but usually & ICD-10: anankastic \\
subsumed & DSM-IV: obsessive-compulsive \\
within cluster C) &
\end{tabular}

Most people with a personality disorder identified by current diagnostic systems have more than one and, as the problems get more severe, so do the number of personality disorders. ${ }^{3}$ The reliability of these categories is also poor, and very few ever reach the agreement level of $\kappa=0.75$ or greater that is considered to be the desirable minimum. ${ }^{4,5}$ Two clear messages arise from the work to date: (i) dimensional ratings of personality are much more reliable than categorical ones; and (ii) the fewer the groupings the greater the agreement. ${ }^{6,7}$ For this reason the notion of clusters of personality disorder has been generated, in which the main groupings are: cluster A, odd, eccentric personalities; cluster $\mathrm{B}$, flamboyant, dramatic personalities; cluster $\mathrm{C}$, anxious, fearful personalities (Table 1). The true psychopathic personality, as described by $\mathrm{Cleckley}^{8}$ and refined by Hare, ${ }^{9}$ is not included in this system except as an extreme variant of antisocial personality disorders with an admixture of other components. ${ }^{10}$

Table 2 Dimensional system of classifying personality disorders (from Refs 11 and 12)

\begin{tabular}{|c|c|c|}
\hline $\begin{array}{l}\text { Level of } \\
\text { severity }\end{array}$ & Description & Definition by categorical system \\
\hline 0 & $\begin{array}{l}\text { No personality } \\
\text { disorder }\end{array}$ & $\begin{array}{l}\text { Does not satisfy actual or } \\
\text { sub-threshold criteria for any } \\
\text { personality disorder }\end{array}$ \\
\hline 1 & Personality difficulty & $\begin{array}{l}\text { Meets sub-threshold criteria for } \\
\text { one or more personality } \\
\text { disorders }\end{array}$ \\
\hline 2 & $\begin{array}{l}\text { Simple personality } \\
\text { disorder }\end{array}$ & $\begin{array}{l}\text { Meets actual criteria for one or } \\
\text { more personality disorders } \\
\text { within the same cluster }\end{array}$ \\
\hline 3 & $\begin{array}{l}\text { Complex (diffuse) } \\
\text { personality } \\
\text { disorder }\end{array}$ & $\begin{array}{l}\text { Meets actual criteria for one or } \\
\text { more personality disorders } \\
\text { within more than one cluster }\end{array}$ \\
\hline 4 & $\begin{array}{l}\text { Severe personality } \\
\text { disorder (also } \\
\text { psychopathy) }\end{array}$ & $\begin{array}{l}\text { Meets criteria for creation of } \\
\text { severe disruption both to } \\
\text { individual and to many in society }\end{array}$ \\
\hline
\end{tabular}

Categorical and dimensional approaches operate by splitting the spectrum of personality disorder into four major groups $-0=$ no personality disorder; $1=$ personality difficulty (or personality accentuation); ${ }^{11} 2=$ simple personality disorder (personality disorder in one cluster only); and $3=$ complex or diffuse personality disorder (personality disorder in more than one cluster). ${ }^{12} \mathrm{~A}$ fourth category can be added for severe personality disorder in which risk and dangerousness are assessed ${ }^{13}$ (Table 2).

\section{Aiding clinical decisions}

Clinical decisions in the management of people with personality disorders remain uncertain since it is only recently that personality disorders have been regarded as suitable for intervention. The most important decision is when and when not to treat the personality disorder directly. Patients differ strikingly in their response to the notion that a therapist might wish to change their personality. Some take great exception to it, whereas others are eager to embark on any treatment that might make them different from the people they are. We have suggested that this is a sufficiently important subject to introduce a new typology into the classification of personality disorder - that of type $\mathrm{R}$ and type $\mathrm{S}$ personalities. ${ }^{14}$

The main differentiating features of type $\mathrm{R}$ (treatmentresisting) and type $S$ (treatment-seeking) personality disorders are shown in Table 3. Patients with type $S$ regard their personalities as alien (i.e. they are egodystonic) and will go to great lengths to effect change. By contrast, those with type $\mathrm{R}$ personality disorders are fiercely protective of their personality features and feel it is others, rather than they themselves, who need to change. Our initial studies suggest that most cluster $\mathrm{C}$ patients fall into the type $\mathrm{S}$ group, schizoid and paranoid personality disordered patients into the type $\mathrm{R}$ one,${ }^{14}$ but this is not exclusive. As clinical interventions become more widely

Table 3 Differences between treatment-resisting (type R) and treatment-seeking (type $\mathrm{S}$ ) personality disorders

\begin{tabular}{lll}
\hline Clinical characteristic & Type R & Type S \\
\hline $\begin{array}{l}\text { Presents with personality as part } \\
\text { of treatment problem }\end{array}$ & No & Yes \\
$\begin{array}{l}\text { Willing to engage in psychological } \\
\text { assessment and treatment }\end{array}$ & Rarely & Yes \\
$\begin{array}{l}\text { Will take drug treatments } \\
\begin{array}{l}\text { Accepting of diagnosis of personality } \\
\text { disorder }\end{array}\end{array}$ & No, or very & Yes \\
$\begin{array}{l}\text { Motivated to change at least } \\
\text { somewhat }\end{array}$ & No & Yes \\
\hline
\end{tabular}


used in personality disorder, the type R and S typology may assume greater importance. Complex interventions requiring considerable commitment by patients (e.g. dialectical behaviour therapy $)^{15,16}$ are only likely to be taken on by type $\mathrm{S}$ personalities, whereas approaches such as nidotherapy (the systematic adjustment of the environment to fit the abnormal personality ${ }^{17}$ ) are much more popular with type $\mathrm{R}$ personalities.

Of the treatments available, only four have clear evidence of efficacy, and all of these are for patients with borderline personality disorder, a heterogeneous group that allows little generalization but which often has a large proportion of type $\mathrm{S}$ personalities. The successful treatments (i.e. those with an acceptable evidence base) are (i) a special form of psychodynamic psychotherapy linked to day-hospital care; ${ }^{18,19}$ (ii) dialectical behaviour therapy, developed by Marsha Linehan in Seattle, for women with borderline personality disorder, ${ }^{15}$ whose treatment effects have been replicated recently; ${ }^{16}$ (iii) cognitive-behaviour therapy specially adapted for personality disorder which has been shown to be cost-effective in a large trial of 480 patients; ${ }^{20,21}$ (iv) antipsychotic and antidepressant drug treatment, in which there is considerable uncertainty about the mechanism of action and choice of disorder suitable for treatment. ${ }^{22} \mathrm{We}$ have no preferred treatments for true psychopathy, and there is some evidence that psychological interventions may be counterproductive. ${ }^{23}$

\section{To improve prediction and prognosis, and aid research}

Until there were accepted treatments for personality disorder it was reasonable to conclude that the outcome of each disorder was the same as the natural history of the condition. Now we are beginning to see a pattern in the natural history of personality disorders that has an important bearing on treatment. Studies of the outcome of cluster B personality disorders suggest that antisocial and histrionic personality disorders improve, to the extent that they are virtually absent in old age, ${ }^{24}$ and that some characteristics of borderline personality disorder, such as impulsiveness, likewise improve ${ }^{25}$ but other abnormalities such as affective disturbance persist. Obsessional, paranoid and schizoid personality traits tend to become more pronounced as people approach middle or old age. ${ }^{26}$

\section{CONCLUSION}

Despite residual difficulties there is now a sound infrastructure for studies to elucidate the cause and refine the description of personality disorders. A break from the failed classification systems of the past twenty years would help to establish the place of the new therapies. More than any refinement of classification, this would help remove the stigma that at present makes many clinicians reluctant to apply the diagnostic label of personality disorder.

\section{REFERENCES}

1 American Psychiatric Association. Diagnostic and Statistical Manual of Mental Disorders. Washington, DC: APA, 1980

2 Schneider K. Die Psychopathischen Persönlichkeiten. Berlin: Springer, 1923

3 Coid J, Kahtan N, Gault S, Jarman B. Patients with personality disorder admitted to secure forensic psychiatry services. BrJ Psychiatry 1999; 175:528-36

4 Cicchetti DV, Sparrow SS. Developing criteria for the rating of specific items in a given inventory. Am J Men Deficiency 1987;86:127-37

5 Zimmerman M. Diagnosing personality disorders. A review of issues and research methods. Arch Gen Psychiatry 1994;51:225-45

6 Widiger TA. Personality disorder dimensional models proposed for DSM-IV. J Personal Disord 1991;5:386-8

7 Clark LA, Harrison JA. Assessment instruments. In: Livesley WJ, ed. Handbook of Personality Disorders: Theory, Research and Treatment. New York: Guilford, 2001:277-306

8 Cleckley H. The Mask of Sanity. London: Henry Kimpton, 1941

9 Hare RD. The Hare Psychopathy Checklist-Revised. Toronto: Multihealth Systems, 1991

10 Blackburn R, Coid JW. Empirical clusters of DSM-III personality disorders in violent offenders. J Personal Disord 1999;13:18-34

11 Leonhard K. Akzentuierte Persönlichkeiten. Berlin: Volk und Gesundheit, 1968

12 Tyrer P, Johnson T. Establishing the severity of personality disorder. Am J Psychiatry 1996;153:1593-7

13 Tyrer P, ed. Challenges for the future. Personality Disorders: Diagnosis, Management and Course. London: Arnold, 2000:126-32

14 Tyrer P, Mitchard S, Methuen C, Ranger M. Treatment-rejecting and treatment-seeking personality disorders: Type $\mathrm{R}$ and Type S.J Personal Disord 2003;72:350-6

15 Linehan MM, Armstrong HE, Suarez A, Allmon D, Heard HL. Cognitive-behavioral treatment of chronically parasuicidal borderline patients. Arch Gen Psychiatry 1991;48:1060-4

16 Verheul R, van den Bosch LMC, Koeter MJW, de Ridder MAJ, Stijnen T, van den Brink W. Dialectical behaviour therapy for women with borderline personality disorder: 12-month, randomised clinical trial in The Netherlands. Br J Psychiatry 2003;182:135-40

17 Tyrer P, Sensky T, Mitchard S. The principles of nidotherapy in the treatment of persistent mental and personality disorders. Psychother Psychosomatics 2003;33:969-76

18 Bateman A, Fonagy P. Effectiveness of partial hospitalization in the treatment of borderline personality disorder: a randomized controlled trial. Am J Psychiatry 1999;156:1563-99

19 Bateman AW, Fonagy P. Treatment of borderline personality disorder with psychoanalytically oriented partial hospitalisation: an 18-month follow-up. Am J Psychiatry 2001;158:36-42

20 Tyrer P, Thompson S, Schmidt U, et al. Randomised controlled trial of brief cognitive behaviour therapy versus treatment as usual in recurrent deliberate self-harm: the POPMACT study. Psychol Med (in press)

21 Byford S, Knapp M, Greenshields J, et al. (on behalf of the POPMACT Group). Cost-effectiveness of brief cognitive behaviour therapy versus treatment as usual in recurrent deliberate self-harm: a rational decision making approach. Psychol Med 2003;33:977-86

22 Soloff PH. Is there any drug treatment of choice for the borderline patient? Acta Psychiatr Scand 1994;89(suppl 379):50-5 
23 Rice ME, Harris GT, Cormier CA. An evaluation of a maximum security therapeutic-community for psychopaths and other mentally disordered offenders. Law Hum Behav 1992;16:399-412

24 Cohen BJ, Nestadt G, Samuels JF, Romanoski AJ, McHugh PR, Rabins PV. Personality disorder in later life: a community study. Br J Psychiatry 1994;165:493-9
25 Stevenson J, Meares R, Comerford A. Diminished impulsivity in older patients with borderline personality disorder. Am $J$ Psychiatry 2003; 160:165-6

26 Seivewright $\mathrm{H}$, Tyrer $\mathrm{P}$, Johnson T. Change in personality status in neurotic disorders. Lancet 2002;359:2253-4 